INTERMARUM: history, policy, culture. - Issue 7.

UDC 94(477)

DOI $10.33287 / 112003$

Stelnykovych Serhii,

Doctor of Historical Sciences, Associate Professor, Professor at the Department of History of Ukraine, Zhytomyr Ivan Franko State University stel-s@ukr.net

ORCID: https://orcid.org/0000-0001-9121-8977

\title{
TRAGEDY IN BAZAR IN THE COMMEMORATIVE PRACTICES OF THE ANTI-BOLSHEVIK INSURGENCY AND UKRAINIAN EMIGRATION IN THE 1920s-1930s
}

\section{Abstract}

The objective of the article is to investigate the commemorative practices related to the tragedy in Bazar in the context of the antiBolshevik insurgency and Ukrainian emigration of the 1920s-1930s. The methodology of the scientific research is based on the general scientific and special historical methods, taking into account the basic principles of historical world perception: historicism, scientific character, objectivity, systematic approach. The principles of historicism and scientific character have made it possible to reproduce the peculiarities of the commemorative practices associated with the tragedy in Bazar in all its complexity and diversity, interrelation and interdependence with the events of the time. The principle of objectivity is a helpful way to analyze the outlined problem with a critical survey of reference data. The principle of the systematic approach has enabled us to form a coherent picture of the manifestations of the commemorative practices in memory of the victims of the tragedy during the outlined period. The scientific novelty of the research lies in the fact that it examines the events of November 1921 from the standpoint of the historical memory schools for the first time. A great variety of reference data has made it possible to examine the commemorative practices in the memory of the victims of the tragedy in Bazar in a short chronological period from the 1920s and during the 1930s. As a result of the study, the author concludes that the first attempts to 
IНТЕРМАРУМ: історія, політика, культура. - Вип. 7.

commemorate the victims at their burial sites occurred in the early 1920s. The preservation of the memory of the tragedy in Bazar fostered the spread of anti-Bolshevik insurgencies in Zhytomyr region. As the Soviet authorities aimed to destroy the historical memory of the victims of the November 1921 execution, the attempts to preserve it through various commemorative practices were connected with the Ukrainian political emigration abroad (Poland, France, and Czechoslovakia) because the former Ukrainian military as well as the emigration government structures of the UNR were situated there. In the interwar period the commemoration of the tragedy in Bazar was embodied and reflected in the works of fine art. Furthermore, memoirs on both the Second Winter Campaign of the UNR Army and the tragedy in Bazar were published during this time.

Key words: commemorative practices, historical memory, tragedy in Bazar, interwar period.

Introduction. The final stage of the Ukrainian Revolution of 1917-1921 were the events of November 21-23, 1921. At that time, the Bolshevik troops executed 359 prisoners of war from the Volyn Group of the Second Winter Campaign of the Ukrainian People's Republic Army (UNR) in the town of Bazar in Zhytomyr region. These events went down in history under the name of «The tragedy in Bazar» (or «Bazar»). The Soviet authorities made every effort to destroy the memory of the massacre of prisoners. Despite this, in the early 1920s, especially in the context of the anti-Bolshevik insurgency, people initiated relevant commemorative practices, including the commemoration of the victims of Bazar. Over time, emigration and people in the Western Ukrainian territories under Polish rule supported this tradition.

The notion of the commemorative practices is interpreted as «a set of actions and objects, such as rituals and ceremonies, monuments and memorial complexes aimed at representing a particular historical narrative that is significant to a large part of the community» (Filiuk, 2017). In the European scientific tradition, various aspects related to commemoration within the development of historical memory schools have been investigated by Richard Ned Lebow, Wulf Kansteiner, Claudio Fogu (Lebow, Kansteiner, Fogu, 2006), Aleida Assmann 
INTERMARUM: history, policy, culture. - Issue 7.

(Assmann, 2014), Pierre Nora (Nora, 2014) and others. In Ukraine, this trend is gaining popularity. The confirmation of this we find in the appearance of a special journal «Ukraina moderna», which contains articles by contemporary Ukrainian, Polish, Russian, Moldovan, German, Israeli researchers of historical memory schools; in the publication of fundamental monographs (Kasianov, 2018; Kyrydon, 2016), and separate publications (Filiuk, 2017); in the organization of a series of conferences held in Rivne, Zhytomyr, Lviv.

Today there is no comprehensive study of the tragedy in Bazar in the framework of historical memory schools. As a rule, some scholars have investigated this issue only contextually. For example, paying attention to the commemoration of Bazar victims in general, Yaroslav Faizulin and Vitalii Skalskyi have episodically characterized the period between the 1920s and 1930s (Faizulin, Skalskyi, 2008, pp. 34-35). The author of this article has previously covered the outlined problem in the same context (Stelnykovych, 2016, pp. 121-125). Yaroslav Tynchenko focused on Bazar commemorative practices in the context of antiBolshevik insurgencies of the early 1920s (Tynchenko, 2013). Valerii Vlasenko touched upon the theme of the 10th anniversary commemoration of Bazar victims in the context of the Ukrainian diaspora in Bulgaria. He characterized the life of the Ukrainian community in Bulgaria during the interwar period (Vlasenko, 2013, pp. 77-93). Thus, an integral study of the tragedy in Bazar in the commemorative practices of the interwar period has remained neglected by researchers.

The objective of the article is to investigate the commemorative practices related to the tragedy in Bazar in the context of the antiBolshevik insurgency and the Ukrainian emigration in the interwar period.

Findings and discussion. Under the Bolshevik regime, commemoration of Bazar victims at their burial sites was next to impossible. The new government aimed to destroy the historical memory of any «counter-revolution» manifestations. However, in the early 1920s, there were some attempts to visit the graves and commemorate the memory of the members of the Volyn Group of the Second Winter Campaign of the UNR Army in November 1921. On April 23, 1923, the Soviet authorities claimed that the relatives of the 
IНТЕРМАРУМ: історія, політика, культура. - Вип. 7.

executed would visit two graves in Bazar, and the burial sites themselves affected politically not only the population of Bazar district (established in 1923) but also of «many other governorates» (State Archives of Zhytomyr Region. Coll. R-28. Aids. 6. Fol. 31. P. 11).

Thus, the historical memory of Bazar (1921) among the local population greatly contributed to the spread of anti-Bolshevik movements in the region. The report of the Korosten District Border Division dated November 10, 1923 stated that the main threat to the Soviet authorities in Bazar district was «the developed Petliura movement among the intelligentsia» (State Archives of Zhytomyr Region. Coll. R-28. Aids. 6. Fol. 31. P. 25). For local rebel units, Bazar graves became a symbol of anti-Bolshevik struggle.

In general, the territory of eastern Volyn (Zhytomyr region) plays an important role in the anti-Bolshevik insurgency in the early 1920s. The development of anti-Bolshevik movements in the region was conditioned, among other things, by the activities of some of the participants of the state-making struggle who stayed in the region after the final stage of the Second Winter Campaign of the UNR Army in November 1921. Under these circumstances in May 1922, the Volyn insurgent army led by Opanas Petryk was established in Zhytomyr region. He managed to escape after the defeat of the Volyn Group of the Second Winter Campaign by Hrygorii Kotovskii's detachment near the village of Mali Minky. The memory of the tragedy in Bazar hold a prominent place in the ideology of the Volyn insurgent army. In the memory of the executed members of the Volyn group of the Second Winter Campaign of the UNR army in Bazar a special detachment «Revenge» (Pomsta) was formed as a part of the Volyn insurgent army. It was led by the head Ivan Zakusilo (Tynchenko, 2013). In the fall of 1922, the members of the Volyn insurgent army were inclined to erect its flag on one of Bazar graves and to begin a general anti-Bolshevik march-off (Counterrevolutionary Movement Led by Petliura before the Proletarian Court. The Verdict on the Case of the Volyn Insurgent Army, 1923, p. 3). However, the plan failed to become a reality, as the Soviet authorities suppressed the underground resistance of the insurgents.

In reaction to any attempts of the local population to honor the memory of the victims of the Bolshevik execution, the Soviet authorities 
INTERMARUM: history, policy, culture. - Issue 7.

would only intensify the propaganda in Bazar district, aimed at forming a cult of the so-called «October Revolution». Its anniversaries fell on November 7 (on October 25 after the Julian calendar) and were supposed to replace any references to Bazar events of November 1921, related to the execution of the members of the Volyn group of the Second Winter Campaign of the UNR Army. On November 18, 1927, at the meeting of Bazar district party committee, it was stated that «due to the early and sufficient preparation, the October holidays were held with enthusiasm and with a large-scale participation of the district population». According to the Soviet authorities, 10515 people took part in the event. At this time, scattered anti-Soviet speeches were made in the villages of Mali Minky and Zvizdal (State Archives of Zhytomyr Region. Coll. P-115. Aids. 1. Fol. 7. P. 117). There was an armed confrontation between the members of the Volyn group of the Second Winter Campaign of the UNR Army and the Bolshevik army in these settlements in November 1921. After this, the festivities devoted to the following anniversaries of the October Revolution in Bazar district only intensified (State Archives of Zhytomyr Region. Coll. P-115. Aids. 1. Fol. 32. P. 202), as well as the ideological propaganda campaign about the Bolsheviks' struggle against the «internal and external counterrevolution» (State Archives of Zhytomyr Region. Coll. P-115. Aids. 1. Fol. 41. P. 215). The actions of the Bolshevik authorities were aimed at silencing and distorting the historical memory of the tragedy in Bazar.

The corresponding ideological campaign of the Soviet authorities was carried out not only in Bazar district but also in Ukraine in general. At the state level, «historical» literature was distributed, which reflected the struggle of the Soviet authorities against the manifestations of the «counterrevolution». It is clear that such «studies» were far from objectivity. At the same time, in the works of the Soviet historians, Bazar events of November 1921 were silenced (Futala, 2012, p. 261).

In June 1923, the Soviet authorities arrested one of the leaders of the Second Winter Campaign of the UNR Army, Yurii Tiutiunnyk. His identity was used in an ideological campaign to discredit the Ukrainian military formations during the revolution and to influence the Ukrainian emigrant community. In 1924, the ambiguous memoirs of Yurii Tiutiunnyk «With Poles against Ukraine» were published in Kharkiv 
IНТЕРМАРУМ: історія, політика, культура. - Вип. 7.

(Tiutiunnyk, 1924). Later the author played himself in the propaganda film «P.K.P.» («Pilsudskii bought Petliura»). The film was shot during the fall of 1925 - spring of 1926 at Odessa Film Studios, and it was released in September 1926. One of the researchers of Yurii Tiutiunnyk's role summarizes the following: «This episode is perhaps the best illustration of the grotesque life of a former rebel headman who was forced to become a caricature of himself» (Faizulin, 2019). The Soviet authorities executed Yurii Tiutiunnyk on October 20, 1930.

Therefore, during the interwar period the commemoration of the tragedy in Bazar was revealed only among the Western Ukrainian emigration, mainly in Europe. The commemoration practices were also evidenced among the residents of Western Ukrainian territories that were under Polish rule. Some of the participants in the Second Winter Campaign of the UNR Army, as well as the Ukrainian Revolution of 1917-1921, were in exile. Therefore, the first events to commemorate the anniversaries of the tragedy in the early 1920s took place in the internment camps of the UNR Army in Poland. Over time, after the elimination of the camps and the acquisition of the political expatriate's status by those who were formerly interned, the commemoration of Bazar victims took place in the countries of compact residence of Ukrainian political emigrants throughout Europe. The corresponding events were also organized in some countries in North and Latin America.

The commemorative practices were evidenced in Poland, France and Czechoslovakia in the first place. After all, some members of the former Ukrainian military as well as the structures of the UNR Emigration Government (UNR State Center) stayed there. Already in the early 1920s the city of Tarny and later Warsaw became the centers of the UNR Government's activity in Poland. The Treaty of Riga between Poland and Soviet Russia led to the loss of a special status of the Ukrainian Government in the territory of Poland. As a result, in the interwar period, the UNR State Center was concentrated in Paris and Prague (Ukrainian People's Republic Government in Exile. Articles and Sources, 1993, p. 70; Marcus, 1986, p. 71). Despite the fact that the Chief Headman (Ataman) of the UNR, Symon Petliura, was living in Paris since 1924 (killed on May 25, 1926), and the President of the UNR State Center, Andrii Livitskyi, as well as some ministers were 
INTERMARUM: history, policy, culture. - Issue 7.

taking action in Prague, Warsaw remained the center of the UNR emigration government until the late 1930s (Marcus, 1986, pp. 72-73).

On November 21, 1929, a memorial service for all those who died in the struggle for the will of Ukraine was held in the Prague Orthodox parish. On the same day, the Ukrainian community organized the event to commemorate those killed in Bazar. Colonel Vasil Filonovych presented a report «1921 Uprising in Ukraine». The commemoration of the next anniversary of the tragedy in Bazar took place on November 23, 1929 in Paris. The following day, a memorial service for the dead was held in the Ukrainian Orthodox Church of the capital of France (Chronicle, 1929, p. 38).

An issue of the non-periodical «Hurtuimosia» magazine (November 1929) was devoted to the $8^{\text {th }}$ anniversary of the tragedy in Bazar. At this time, the publication was published in Prague with the support of the UNR Emigration Government.

In November 1930 in France, Ukrainian emigrant organizations, including the Association of Former UNR Army Soldiers, celebrated the $9^{\text {th }}$ anniversary of the tragedy on a large scale. One of the issues of the «Tryzub» magazine in 1930, published in Paris as the unofficial printed publication of the UNR emigration government, states:

"The day of Bazar in November, the day of the heroic death of 359 soldiers near the village of Bazar in Volyn, is the day of national pride and glory of the Ukrainian army. The death is full of beauty, courage, greatness of spirit: these 359 humble warriors cannot be forgotten, because our young generation will be brought up for heroic acts, for the final realization of our national idea following their example, as a rare one in the history of the people" (From the life of Ukrainian emigration in France, 1930, p. 23).

In the French town of Le Creusot, to honor the memory of the executed Ukrainian soldiers, the members of the Association of Former Soldiers of the UNR Army laid a wreath at the monument to those who died in the Great War (From International Life, 1930, p. 17).

The events to commemorate the victims continued on the 10th anniversary of the tragedy in Bazar (Faizulin, Skalskyi, 2008, pp. 3435 ) in the centers of Ukrainian community residence abroad. For example, the Ukrainian Community of Bulgaria held rather large-scale events at the end of 1931. At the same time, the representatives of the 
IНТЕРМАРУМ: історія, політика, культура. - Вип. 7.

Polish and Bulgarian as well as Polish communities joined the Ukrainians. Apart from the memorial service for the executed, a number of reports were made, the «Testament» of T. Shevchenko and the hymn «Ukraine has not died yet» were performed (Vlasenko, 2013, p. 83).

In November 1931, the next issue of the «Hurtuimosia» magazine was dedicated to the events of November 1921. The magazine contained a list of the 359 executed Ukrainian soldiers in Bazar, reminiscences about the UNR Army's Second Winter Campaign, the Bolshevik execution, theme songs, etc. Anonymous reminiscences about the execution of the Ukrainian military, in particular, state:

"The experience of 10 years ago is like fog. Only the facts that have fallen deep into the memory possess clear features. Over time, I think, they will become more and more obscure. On the day of November 17 (the day of the battle near the village of Mali Minky) and on the day of November 22 (the day of the 359 execution) let each of the Ukrainians remember those who died but believed and wanted to liberate their native land from the executioners and occupants" (November 1921, 1931, p. 27).

By the way, it was the «Hurtuimosia» magazine that actively reported on the activities of the Ukrainian diaspora in different countries of Europe to commemorate the anniversary of the tragedy. The publication, which was published in early 1935, contained a reproduction of a painting «Bazar» by UNR Army Colonel Mykola Bytynskyi («Execution of 359 Martyrs in Bazar»). It depicted the Bolshevik Execution of the Ukrainian military in Bazar in November 1921 (the original painting was in the S. Petliura's Library in Paris). In addition to the reproduction, there was an excerpt from speeches of Ukrainian soldiers at the November 1921 execution in Bazar:

"...Foremen and Rifles! We die for the Will of our people... Our death will not be forgiven to our enemies and we will not be forgotten among the Native People... We will consciously die for the Will and for Ukraine... Glory! Glory! ...” (Bytynskyi, 1935, p. 21).

The issue also contained a reproduction of the painting by Mykhailo Mykhalevych, the central part of which was occupied by a symbolic image of the cross with the «359» inscription (Mykhalevych, 1935 , p. 25). These images, presented on the pages of periodicals, in particular in the magazine «Hurtuimosia», testify to the presence of 
INTERMARUM: history, policy, culture. - Issue 7.

works of fine art among other commemorative practices of the tragedy in Bazar.

The emigration intensified the attention to Bazar events in November 1936 during the commemoration of the $15^{\text {th }}$ anniversary of the tragedy. In particular, on November 29, 1936, thematic events initiated by the Ukrainian Community took place in Lyon. The deputy chairman of the Ukrainian Community Halaida said in his report that:

"all peoples have their dear graves, which they worship, we also have such graves, and one of them houses 359 best sons of Ukraine, who address the living and unborn countrymen in Ukraine and not in Ukraine and remind what they laid down their lives for" (From the Life of Ukrainian Emigration in France, 1936, p. 21).

After numerous speeches and a minute of remembrance, the report ended with a joint performance of the national anthem. On November 29, 1936, apart from Lyon, the commemoration of Bazar victims also took place in Auden-le-Tisch. It was organized by a branch of the Association of Former Soldiers of the UNR Army in France. In the west of France the children's choir of a local Ukrainian school performed the anthem «Ukraine has not died yet»; a report on the history of the November events of 1921 was made, mentioning the names of the 359 executed; people performed «Eternal Memory», etc. (From the Life of Ukrainian Emigration in France, 1936, p. 22).

As it was mentioned above, during the interwar period the commemorative practices of the tragedy in Bazar among emigrants, apart from France and Czechoslovakia, were also evidenced in Poland. In fact, in the pre-war period in Warsaw apart from the presence of a large number of Ukrainian political emigrants, there also functioned the UNR Emigration State Center headed by President Andrii Livytskyi. On November 22, 1936, the Orthodox Cathedral of Warsaw at the initiative of the Ukrainian Central Committee held a funeral service in the presence of a significant number of the Ukrainians. On the same day, the Ukrainian Student Community organized thematic events in the Polish capital (Warsaw Ukrainians to the Heroes of Bazar, 1936, p. 6). On November 28, 1936 in Warsaw the corporation «Zaporozhzha», headed by Petro Kholodnyi held «Bazar Holiday». In the west, Andrii Kryzhanivskyi noted that Bazar was «rather a joyous than a sad episode, 
IНТЕРМАРУМ: історія, політика, культура. - Вип. 7.

because it is a heroic and creative moment in the Ukrainian state competitions» (In Poland, 1936, p. 23).

At the same time, the events to commemorate the $15^{\text {th }}$ anniversary of Bazar tragedy took place in the western Ukrainian territory, first of all in Lviv, Ternopil, Stanislaviv (Ivano-Frankivsk), other cities and villages of the region. Often the commemoration of the victims, which would turn into the national manifestations, was accompanied by the speeches of former participants of the Second Winter Campaign of the UNR Army (The Bow to the Heroes of Bazar in Stanislavov, 1936, p. 6; Bazar Anniversary, 1936, p. 7).

The commemoration of the executed in Bazar both in emigration and in the western Ukraine continued in the years to come. On November 27, 1938, at the initiative of the Division of the Ukrainian Central Committee in Lodz, a memorial service was held for those shot dead in Bazar where Father Boretskyi delivered a long speech (In Poland, 1939, 12, p. 15). In late November - early December 1938, the commemoration of the executed took place in Kovel district, where at the urging of priest Ivan Guba, the population donated to the Union of the Disabled Ukrainians, located in the Polish city of Kalisz (In Poland, 1939, 1-2, pp. 44-45).

In its turn, the UNR Emigration State Center joined the commemorative practices associated with the tragedy in Bazar at the highest political level. In early 1939, it awarded 359 members of the Volyn Group of the Second Winter Campaign of the UNR Army, executed by the Bolsheviks in November 1921 the crosses of Symon Petliura (posthumously). The participants of the struggle for state independence of Ukraine shot in Bazar were given the distinctions with the numbers 2001-2359 (Tynchenko, 2016, p. 137).

During the interwar period, a considerable number of memoirs appeared both about the Campaign itself and the Bolshevik execution of November 1921. They were mainly written by the Second Winter Campaign of UNR Army participants. In the first place, the reminiscences were published on the pages of the Prague magazine «Hurtuimosia» and the Parisian magazine «Tryzub». The calendar «Chervona Kalyna», published in Lviv in 1930, contained voluminous reminiscences of Colonel Roman Sushko, a participant of the Second Winter Campaign titled «Bazar. The grave of 359 heroes» (Ovad, 2006, 
INTERMARUM: history, policy, culture. - Issue 7.

pp. 230-243). Roman Sushko called Bazar bed of honor «a witness of the last breakdown in the liberation contest, the last tragic act of the great saga of 1917-1921»(Ovad, 2006, p. 230). A considerable number of reminiscences about Bazar were published in 1932 in the third part of the journal «For Statehood. Materials on the History of the Ukrainian Army». The collection was published in Kalish at the initiative of the Ukrainian Military Historical Society (For Statehood. Materials to the History of the Ukrainian Army, 1932).

Conclusions. The tragedy in Bazar (the execution of 359 members of the Volyn group of the Second Winter Campaign of the UNR Army by the Bolsheviks) became the tragic end of the Ukrainian Revolution of 1917-1921. As early as the beginning of 1920s, corresponding commemorative practices related to the tragedy in Bazar and the remembrance of the executed started to be organized. Their preservation was one of the reasons for the spread of anti-Bolshevik insurgencies, especially in Zhytomyr region. At the same time, the Soviet authorities took measures to destroy the historical memory about Bazar. In this regard, the commemorative practices related to the tragedy in Bazar manifested themselves during the interwar period in emigration, in the places of compact residence of the Ukrainian political emigration, where the structures of the emigration government of the UNR were located (Poland, France, Czechoslovakia).

\section{BIBLIOGRAPHY}

Assmann, A. (2014). Long Shadow of the Past: Memorial Culture and Historical Politics. Moscow: New Literary Overview. 328 p. [In Russian].

Bazar Anniversary. (1936). Case, November 29, 7. [In Ukrainian].

Bytynskyi, M. (1935). Bazar. Hurtuimosia, January-March 21. [In Ukrainian].

Chronicle. (1929). Hurtuimosia, November 21, 38-39. [In Ukrainian].

Counterrevolutionary Movement Led by Petliura before the Proletarian Court. The Verdict on the Case of the Volyn Insurgent Army. (1923). Volyn Proletarian, March 21, 3. [In Russian].

Faizulin, Ya. (2019). KGB Archive Documents Reveal Backstage Mysteries of the Propaganda Film «P.K.P.» («Pilsudskii bought 
ІНТЕРМАРУМ: історія, політика, культура. - Вип. 7.

Petliura»). https://uinp.gov.ua/pres-centr/novyny/dokumenty-z-arhivivkgb-rozkryvayut-zakadrovi-tayemnyci-filmu-agitky-pkp-pilsudskyykupyv-petlyuru [In Ukrainian].

Faizulin, Ya., Skalskyi, V. (2008). Transcripts of the Ukrainian Revolution. The Second Winter Campaign of the UNR Army. Kyiv: Olena Teleha Publishing House. 41. [In Ukrainian].

Filiuk, K. (2017). The Art of Reminding: How the World Honors the Memory of the Tragic Events of the Past. The Ukrainian Truth. https://life.pravda.com.ua/culture/2017/03/13/223078/ [In Ukrainian].

For Statehood. Materials to the History of the Ukrainian Army (1932). 3, 273. [In Ukrainian].

From International Life. (1930). Tryzub, 47, 16-18. [In Ukrainian].

From the Life of Ukrainian Emigration in France (1930). Tryzub, 47, 23-26. [In Ukrainian].

From the Life of Ukrainian Emigration in France. (1936). Tryzub, 43-44, 21-22. [In Ukrainian].

Futala, V. (2012). Military-political Emigration of Ukrainian People's Republic in Interwar Poland: Problem Study State to 1991. Military Scientific Journal, (18), 252-264. [In Ukrainian].

In Poland. (1936). Tryzub, 43-44, 22-23. [In Ukrainian].

In Poland. (1939). Tryzub, 12, 13-15. [In Ukrainian].

In Poland. (1939). Tryzub, 1-2, 43-45. [In Ukrainian].

Kasianov, H. (2018). Past Continuous: Historical Politics of the 1980s-2000s. Ukraine and Neighbors. Kyiv: Laurus. 420 p. [In Ukrainian].

Kyrydon, A. (2016). Memory Heterotypes. Theoretical and Methodological Historical Memory Schools. Kyiv: Nika-Tsentr. 320 p. [In Ukrainian].

Lebow, R., Kansteiner, W., Fogu, C. (eds.) (2006). The Politics of Memory in Postwar Europe. Duke University Press, Durham and London. $384 \mathrm{p}$.

Markus, V. (1986). Exile Government of Ukrainian People's Republic in the Interwar Period (1921-1939). International-Legal and Comparative Analysis. Modern Times, (12), 70-84. [In Ukrainian].

Mykhalevych, M. (1935). Hurtuimosia, January-March 25. [In Ukrainian]. 
INTERMARUM: history, policy, culture. - Issue 7.

Nora, P. (2014). Today, Nation, Memory. Kyiv: Klio, 2014. 272 p. [In Ukrainian].

November 1921. (1931). Hurtuimosia, November, 23-27. [In Ukrainian].

Ovad, Kh. (2006). Colonel Roman Shushko (1894-1944). Documents, Materials, Reminiscences, Dairies, Letters, Photos. Toronto. 305. [In Ukrainian].

State Archives of Zhytomyr Region. Coll. P-115. Aids. 1. Fol. 32. $248 \mathrm{p}$.

State Archives of Zhytomyr Region. Coll. P-115. Aids. 1. Fol. 41. $436 \mathrm{p}$.

State Archives of Zhytomyr Region. Coll. P-115. Aids. 1. Fol. 7. $162 \mathrm{p}$.

State Archives of Zhytomyr Region. Coll. R-28. Aids. 6. Fol. 31. $30 \mathrm{p}$.

Stelnykovych, S. (2016). Tragedy in Bazar on November 21, 1921 in Historical Memory of the Ukrainian People. IV All-Ukrainian Scientific Conference Proceedings «The Problems of Ukrainian Liberation Movement in the $20^{\text {th }}$ Century (dedicated to the $75^{\text {th }}$ anniversary of Polessie Sich and to the $95^{\text {th }}$ anniversary of the Second Winter Campaign)», 121-125. [In Ukrainian].

The Bow to the Heroes of Bazar in Stanislavov. (1936). Case, November 27, 6. [In Ukrainian].

Tiutiunnyk, Yu. (1924). With Poles against Ukraine. Kharkiv: State Publishing House. 107. [In Ukrainian].

Tynchenko, Ya. (2013). Recusant Volyn. Ukrainian Week. https://tyzhden.ua/History/86129 [In Ukrainian].

Tynchenko, Ya. (2016). Award Case of Ukrainian People's Republic Governments, 1917-1992. Thesis for a Candidate Degree in Historical Sciences. Kyiv. 251. [In Ukrainian].

Ukrainian People's Republic Government in Exile. Articles and Sources. (1993). Philadelphia, Kyiv, Washington. 494 p. [In Ukrainian].

Vlasenko, V. (2013). Ukrainian Community in Bulgaria in the Interwar Period (a Case Study of Parisian Weekly Publication «Tryzub». Dragomanov Schools. The $6^{\text {th }}$ and $7^{\text {th }}$ Conference Proceedings, 77-93. [In Ukrainian]. 
IНТЕРМАРУМ: історія, політика, культура. - Вип. 7.

Warsaw Ukrainians to the Heroes of Bazar. (1936). Case. November 27, 6. [In Ukrainian].

\section{Стельникович Сергій. БАЗАРСЬКА ТРАГЕДІЯ В КОМЕМОРАТИВНИХ ПРАКТИКАХ АНТИБІЛЬШОВИЦЬКОГО ПОВСТАНСЬКОГО РУХУ ТА УКРАЇНСЬКОЇ ЕМІГРАЦЇ 1920-x - 1930-х pp. Анотація}

Метою статті $е$ дослідження комеморативних практик, пов'язаних з Базарською трагедією, у середовищі антибільшовииького повстанського руху та украӥнської еміграції 1920-x-1930-х рp. Методологія наукового дослідження грунтується на основі загальнонаукових $і$ спеціальних історичних методів з урахуванням базових принципів історичного пізнання: історизму, науковості, об'єктивності, системності. Принциипи історизму та науковості дозволили відтворити комеморативні практики, пов'язані з Базарською трагедією, в усій складності та багатоманітності, у взаємозв'язку $i$ взаємозумовленості 3 тогочасними подіями. Принции об'єктивності допоміг підійти до розгляду окресленої проблематики з урахуванням об'єктивних історичних закономірностей, з критичним аналізом літературноджерельної бази. Принщип системності дозволив сформувати цілісну картину відповідних комеморативних практик. Наукова новизна роботи полягає в тому, шуо тут уперше на основі широкої джерельної бази розглянуто Базарську трагедію в комеморативних практиках 1920-х-1930-х рр. У результаті автор приходить до висновку, щзо перші спроби вщанування пам'яті загиблих на місиях їх поховання відбулися на початку 1920-х рр. При иььму пам'ять про Базарську трагедію сприяла поширенню антибільшовицьких повстанських рухів на Житомирщині. Оскільки радянська влада спрямувала зусилля на знищення історичної пам'яті про жертв розстрілу листопада 1921 р., відповідні комеморативні практики проявилися переважно у середовищі української політичної еміграчії за кордоном (у Польщі, Франиії, Чехословаччині). Адже тут разом з перебуванням частини колишніх українських військових розмішувалися структури еміграційного Уряду УНР. У міжвоєнний період комеморативні 
INTERMARUM: history, policy, culture. - Issue 7.

практики про Базар відобразилися в образотворчому мистецтві. Також в цей час були опубліковані спогади, присвячені як Другому зимовому походу Армії УНР, так і Базарській трагедї.

Ключові слова: комеморативні практики, історична пам'ять, Базарська трагедія, міжвоєнний період.

\section{Stelnikowicz Sergiej. TRAGEDIA POD BAZAREM W PAMIĄTKOWYCH PRAKTYKACH POWSTAŃCZEGO RUCHU ANTYBOLSZEWICKIEGO I EMIGRACJA UKRAIŃSKA W LATACH 1920-1930}

\section{Streszczenie}

Celem artykutu jest zbadanie praktyk pamiatkowych zwiazanych z tragedia pod Bazarem $w$ środowisku powstań antybolszewickich $i$ emigracji ukraińskiej $w$ latach 1920-1930. Metodogolia naukowego badania opiera się na ogólnonaukowych $i$ specjalnych metodach historycznych, biorac do uwagi podstawowe zasady poznania historycznego, czyli historyzmu, naukowości, obiektywizmu, systematyczności. Zasady historyzmu i naukowości umożliwity odtworzenie osobliwości praktyk pamiatkowych zwiazanych z tragedia pod Bazarem, w całej swojej komplikacji i różnorodności, w zwiazku $i$ współzależności z wydarzeniami tamtych czasów. Zasada obiektywności pomogła zbliżyć się do przedstawionych problemów za pomoca krytycznej analizy źródet literackich. Zasada systematyczności pozwoliła nam stworzyć całościowy obraz praktyk pamiatkowych przy uhonorowaniu ofiar tragedii $w$ tamtym czasie. Orygilnościa naukowa pracy jest to, że po raz pierwszy zbadano wydarzenia z listopada $1921 \mathrm{r}$. przez optykę studii pamięci. Na podstawie szerokiej bazy źródłowej zostaty zbadane praktyki pamiatkowe uhonorowania ofiar tragedii pod Bazarem w krótkim okresie chronologicznym, w latach 1920-1930.

$W$ wyniku badań autor stwierdza, że pierwsze próby uhonorowania pamięci ofiar w miejscach ich pochówku były już na początku lat 20. XX wieku. Jednocześnie przechowywanie pamięci o tragedii pod Bazarem przyczyniło rozprzestrzenianie antybolszewickich ruchów powstańczych na Żytomierszczyźnie. Ponieważ, władze radzieckie przekierowali swoje wysitki do zniszczenia pamięci historycznej o ofiarach rozstrzelania $w$ listopadzie 1921 r., próby jej przechowywania za pomoca różnych praktyk pamiatkowych wiąano ze środowiskiem ukrainskiej emigracji 
IНТЕРМАРУМ: історія, політика, культура. - Вип. 7.

politycznej za granice (w Polsce, Francji i Czechosłowacji). W końcu wraz z pobytem tutaj części byłego ukraińskiego wojska mieścity się struktury rządu emigracyjnego UNR. W okresie międzywojennym pamięć o Bazarze została wcielona $i$ odzwierciedlona $w$ dziełach sztuki. Również $w$ tym czasie zostały opublikowane wspomnienia dotyczace zarówno drugiej zimowej kampanii armii UNR, jak $i$ tragedii pod Bazarem.

Stowa kluczowe: praktyki pamiatkowe, pamięć historyczna, tragedia pod Bazarem, okres międzywojenny.

The article was received 09.17.2019 Article recommended for publishing 10.23.2019 